\title{
Memory impairments and increased GFAP expression in hippocampal astrocytes following hypercaloric diet in rats
}

\author{
Prejuízos de memória e expressão aumentada de GFAP em astrócitos hipocampais após \\ dieta hipercalórica em ratos
}

Eduardo Fernandes BONDAN ${ }^{1,2}$, Carolina Vieira CARDOSO', Maria de Fátima Monteiro MARTINS², Rosemari OTTON ${ }^{3}$

\begin{abstract}
Objective: Hypothalamic inflammation and glial fibrillary acidic protein (GFAP) overexpression in astrocytes are well described in obese animals, as are some cognitive and memory deficits. As the hippocampus plays important roles in the consolidation of information, this investigation aimed to observe the memory function and the astrocyte expression of GFAP in the hippocampus of rats that received either a hypercaloric or a normocaloric diet. Methods: Adult male Wistar rats received a high-fat (cafeteria) or a standard diet for 60 days. On the $61^{\text {st }}$ day, the rats were submitted to the novel object recognition (NOR) test at three and 24 hours after the first contact with objects, to assess short-term and long-term memory, respectively. Thereafter, the rats were euthanized and their brains were collected for GFAP immunohistochemical investigation in the hippocampus (CA1, CA2, CA3 areas) and hypothalamus (periventricular and arcuate nuclei). Astrocytic reactivity was assessed by morphometry. Different white adipose tissue depots and brown adipose tissue were weighed to calculate the adiposity index. Results: The hypercaloric diet increased body weight gain, adiposity index, white adipose tissue weight (epididymal, subcutaneous and retroperitoneal) and brown adipose tissue weight. Rats fed with the hypercaloric diet showed short-term and long-term memory impairments in the NOR test, as well as increased GFAP expression in astrocytes from all analyzed hypothalamic and hippocampal areas. Conclusion: This astrogliosis suggests that the neuroinflammatory response also occurs in the hippocampus and may be involved in the memory losses observed in obese/overweight animals.
\end{abstract}

Keywords: Astrocytes; hippocampus; immunohistochemistry; memory disorders; obesity.

\section{RESUMO}

Objetivo: A inflamação hipotalâmica e a superexpressão da proteína glial fibrilar ácida (GFAP) em astrócitos são bem descritas em animais obesos, assim como déficits cognitivos e de memória. Como o hipocampo desempenha importante papel na consolidação de informações, esta investigação teve como objetivo observar a função da memória e a expressão astrocitária da GFAP no hipocampo de ratos que receberam dieta hipercalórica ou normocalórica. Métodos: Ratos Wistar machos adultos receberam dieta rica em gordura (cafeteria) ou dieta padrão por 60 dias. No $61^{\circ}$ dia, os ratos foram submetidos ao teste de reconhecimento de objetos (NOR) 3 e 24 horas após o primeiro contato com os objetos, para avaliação da memória de curto e de longo prazo, respectivamente. Após, os ratos foram eutanasiados e os encéfalos coletados para pesquisa imuno-histoquímica da expressão astrocitária de GFAP no hipocampo (áreas CA1, CA2 e CA3) e no hipotálamo (núcleos periventricular e arqueado). A reatividade astrocitária foi avaliada por morfometria. Diferentes depósitos de tecido adiposo branco e marrom foram pesados para calcular o índice de adiposidade. Resultados: A dieta hipercalórica aumentou o ganho de peso corporal, o índice de adiposidade, o peso do tecido adiposo branco (epididimal, subcutâneo e retroperitoneal) e marrom. Ratos alimentados com dieta hipercalórica apresentaram prejuízos na memória de curto e longo prazo no teste NOR e aumento da expressão de GFAP em astrócitos de todas as áreas hipotalâmicas e hipocampais analisadas. Conclusão: Esta astrogliose sugere que a resposta neuroinflamatória também ocorre no hipocampo, podendo estar envolvida nas perdas de memória observadas em animais obesos/com sobrepeso.

Palavras-chave: Astrócitos; hipocampo; imuno-histoquímica; transtornos de memória; obesidade.

${ }^{1}$ Universidade Paulista, Programa de Pós-Graduação em Patologia Ambiental e Experimental, São Paulo SP, Brasil;

¿Universidade Cruzeiro do Sul, Escola de Medicina Veterinária, São Paulo SP, Brasil;

${ }^{3}$ Universidade Cruzeiro do Sul, Programa de Pós-Graduação em Ciências da Saúde, São Paulo SP, Brasil.

Eduardo Fernandes Bondan (ID https://orcid.org/0000-0002-3887-0023; Rosemari Otton (iD) https://orcid.org/0000-0001-5503-3967

Correspondence: Eduardo Fernandes Bondan; Programa de Pós-Graduação em Patologia Ambiental e Experimental, Universidade Paulista; Rua Dr. Bacelar, 1212; 04026-002 São Paulo SP, Brasil; Email: bondan@uol.com.br.

Conflict of interest: There is no conflict of interest to declare.

Support: This research was supported by the National Council for Scientific and Technological Development (CNPq).

Received 30 January 2019; Received in final form 31 March 2019; Accepted 02 May 2019. 
Recent investigations in animals and humans suggest that obesity may be associated with learning and memory deficits and, in particular, with reductions in episodic memory ${ }^{1,2}$. There is consistent evidence of impaired memory performance in obese rats ${ }^{3,4}$ although some studies have not found an association with cognition or memory ${ }^{2}$. Lying deep in the medial temporal lobes, the hippocampal formation is one of the most-studied neuronal systems in the brain $^{5}$. It plays a critical role in the formation, organization, and storage of new memories as well as connecting certain sensations and emotions to these memories ${ }^{5,6,7}$. Although the hippocampus appears to be crucial for long-term episodic memory, its precise role remains unclear as it is not yet fully understood how this brain structure's individual regions are involved in the formation of memories ${ }^{6,7}$.

Obesity is also associated with the development of many diseases such as heart disease, hypertension, dyslipidemia and atherosclerosis, type 2 diabetes, and cancer, as well as promoting a chronic low-grade inflammatory response in peripheral tissues ${ }^{8}$, including the central nervous system (CNS). Hypothalamic inflammation is considered an early and determining factor for the onset of obesity, a fact that occurs even before body weight gain $^{9,10,11}$. In the mouse hypothalamus, regional astrogliosis has been observed in response to obesity, with increased expression of the astrocyte marker glial fibrillary acidic protein (GFAP), which could be seen as a sign of neuroinflammation associated with the microvasculature ${ }^{12}$. Because of their physical proximity to blood vessels, and their function in transporting nutrients, astrocytes are directly affected by nutrient excess, leading to hypothalamic astrogliosis ${ }^{12}$. Later, it was shown that other CNS areas presented the same type of astrocyte response, such as the parietal and frontal cortex, the corpus callosum, the nucleus accumbens, the pons and the molecular and granular layers of the cerebellum ${ }^{13}$.

The aim of this investigation was to determine if a hypercaloric (cafeteria) diet could induce memory impairment and if the hippocampus could also present an astrocyte reaction similar to that observed in other rat brain areas, which could help elucidate the genesis of mnemonic losses in obesity.

\section{METHODS}

\section{Animals}

The animal procedures were performed in accordance with the guidelines of the Ethics Committee on Care and Use of Laboratory Animal Resources, which approved the study protocol (CE/UCS, protocol no. 0153/2011). Mead's resource equation was used to estimate the sample size. Two-month old male Wistar rats $(\mathrm{n}=20)$, weighing $200 \pm 20 \mathrm{~g}$ at the beginning of the study, were housed in plexiglass cages (five rats/cage), under standard laboratory conditions: 12 hour light/dark cycle; lights on at 7:00 a.m.; $22 \pm 1^{\circ} \mathrm{C}$; water and a standard rodent chow (Nuvilab).

\section{Diet and groups}

A standard rodent chow was provided for all experimental animals ad libitum during adaptation for 10 days. The rats were then divided into two groups ( $\mathrm{n}=10$ per group) that received a standard control diet (normocaloric diet, ND group) or a high-fat (38\%) cafeteria diet (hypercaloric diet, HD group) for 60 days. The quantity of food offered to the rats was determined according to a pair-feeding regime. The food items in the cafeteria diet were chosen to reflect the enormous variety, palatability and energy density of the modern western diet. They included standard rodent chow (37.5\%), peanut (12.5\%), cornstarch biscuit (12.5\%), condensed milk (12.5\%) and chocolate $(25 \%)$. This diet provided an average of $4.2 \mathrm{kcal} / \mathrm{g}, 38 \%$ energy as fat, $14 \%$ protein, and $48 \%$ carbohydrate. The standard commercial rodent chow (Nuvilab) provided $2.8 \mathrm{kcal} / \mathrm{g}$, $13 \%$ energy as fat, $32 \%$ protein, and $55 \%$ carbohydrate. The body weight of the rats was measured twice a week.

\section{Novel object recognition (NOR) test}

Following the completion of the 60-day experimental period, the rats were placed for five minutes in an open field arena, to evaluate the recognition of a new object, with the presence of three objects of the same color, size and shape, and being relatively heavy to prevent the rat from moving them. Interaction with these objects in this first test was employed to ensure that there would be no intrinsic preferences or aversions and that each object would be explored for similar durations (habituation phase). For the assessment of short-term and long-term memory ${ }^{14}$, the animals were placed in the open field again, at three and 24 hours after habituation, respectively, with the presence of three objects, one of which was new to the animal (with a different color, shape and size from the other two objects). Exploration was considered as the act of directing the nose toward the object at a distance of no more than $2 \mathrm{~cm}$ and/or touching the object with the nose or mouth ${ }^{15,16}$. The trials were videotaped for five minutes and then analyzed. The evaluated parameters were the interaction time with the new object (in seconds) and the interaction time with the old objects (in seconds).

\section{Sample collection and processing procedures}

Shortly after performing the novel object recognition (NOR) test, the rats were euthanized by decapitation, during the first five hours of the light cycle. Different white adipose tissue (WAT) depots - epididymal, subcutaneous and retroperitoneal - and brown adipose tissue were removed and weighed to calculate the adiposity index. The adiposity index was calculated as the sum of all the fat pad depots per animal and expressed per $100 \mathrm{~g} /$ body weight. The brains were collected and fixed in $10 \%$ buffered formalin for 72 hours. 
Coronal sections of each brain were made to reach the hippocampus (coordinates $4.32 \mathrm{~mm}$ from the interaural line and $-4.68 \mathrm{~mm}$ from the bregma) and the periventricular/arcuate areas of the hypothalamus (coordinates $5.52 \mathrm{~mm}$ from the interaural line and $-3.48 \mathrm{~mm}$ from the bregma $)^{17}$. The tissue was embedded in paraffin for processing for conventional histological procedures.

\section{Glial fibrillary acidic protein immunohistochemistry and morphometry}

The GFAP immunohistochemistry was performed using the chain polymer-conjugated staining method (DAKO EnVision System). We used polyclonal rabbit anti-GFAP immunoglobulin (1:50; Z033401, Dako, Glostrup, Denmark) as the primary antibody followed by the EnVision+ Kit (HRP. Rabbit. DAB+, K4011, Dako, Glostrup, Denmark). Three sections ( $5 \mu \mathrm{m}$ thick) per rat were made and, from each individual section and using a 40x objective, five photomicrographs were taken of the CA1, CA2 and CA3 areas of the hippocampus and of the periventricular and arcuate nuclei of the hypothalamus. The area of GFAP+ astrocyte-like cells and their processes, marked in brown, was automatically calculated, in pixels, using the MetaMorph 6.3 software (Molecular Devices, Sunnyvale, CA, USA), calibrated with digital color filters regulating red, green and blue bits, in such a way that only positive cells were included and the background staining was excluded from the measurement.

\section{Statistical analysis}

Normality was verified using the Kolmogorov-Smirnov test. The Student's T test (for body weight and adiposity parameters), and two-way ANOVA followed by the Bonferroni post hoc test (for results of the NOR test) or Mann-Whitney U test ( for GFAP expression) were used. Results were expressed as means \pm standard errors of the means. In all cases, results were considered significant at $\mathrm{p}<0.05$.

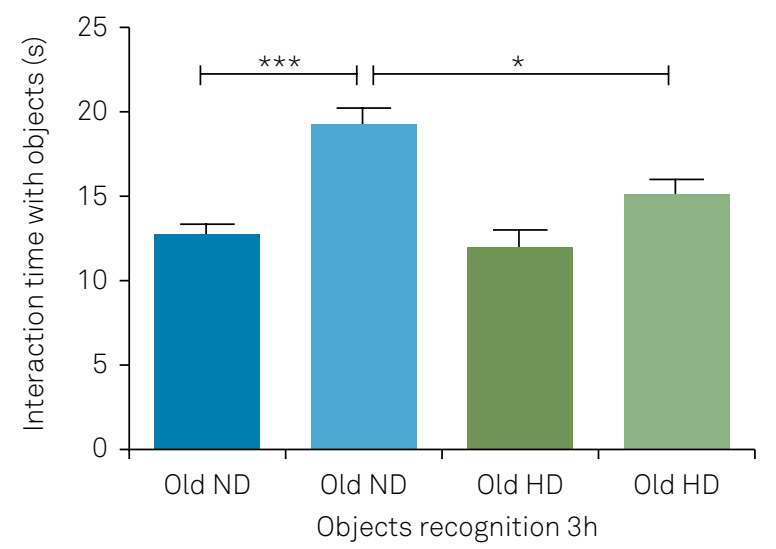

\section{RESULTS}

Final body weight, body weight gain and fat pad mass were measured and are presented in the Table. Although no significant difference was seen in the final body weight between the HD and ND groups, rats fed with the HD showed increased body weight gain; epididymal, subcutaneous, and retroperitoneal white adipose tissue; and brown adipose tissue; as well as an increased adiposity index $(\mathrm{p}<0.05)$.

In the NOR test performed three hours after habituation, rats from the HD group showed a shorter time of interaction with the new object when compared with those from the ND group ( $<<0.05$; Figure 1$)$. The same result was seen in the NOR task after 24 hours ( $<0.0001$; Figure 1). It was also noted that rats from the HD group did not show a different interaction time between the new and the old object, contrary to that observed in the ND group at three hours $(\mathrm{p}<0.001)$ and 24 hours $(\mathrm{p}<0.0001)$ after habituation.

Table. Body weight and fat pad mass.

\begin{tabular}{lcc}
\hline Variable & ND group & HD group \\
\hline Final body weight $(\mathrm{g})$ & $453.3 \pm 10.21$ & $469.7 \pm 22.21$ \\
Body weight gain $(\mathrm{g})$ & $203.5 \pm 11.7$ & $271.3 \pm 15.2^{\mathrm{a}}$ \\
Adiposity index $(\mathrm{g})$ & $14.2 \pm 2.1$ & $27.25 \pm 1.59^{\mathrm{a}}$ \\
Epididymal WAT (g) & $6.05 \pm 0.27$ & $9.39 \pm 0.80^{\mathrm{a}}$ \\
Subcutaneous WAT (g) & $4.27 \pm 0.51$ & $7.92 . \pm 0.99^{\mathrm{a}}$ \\
Retroperitoneal WAT (g) & $3.49 \pm 0.2$ & $7.58 \pm 0.84^{\mathrm{a}}$ \\
Brown adipose tissue (g) & $0.53 \pm 0.04$ & $0.69 \pm 0.06^{\mathrm{a}}$ \\
\hline
\end{tabular}

Final body weight (g), body weight gain (g), epididymal white adipose tissue weight (g/100g), subcutaneous white adipose tissue weight (g/100g), retroperitoneal white adipose tissue weight $(\mathrm{g} / 100 \mathrm{~g})$ and brown adipose tissue weight $(\mathrm{g} / 100 \mathrm{~g})$. Data are presented as mean $\pm \mathrm{SEM}$ of 10 rats per group. WAT: white adipose tissue; ND group: rats fed with normocaloric (standard control) diet; HD group: rats fed with hypercaloric (cafeteria) diet. a: statistically significant difference compared with the ND group. $p<0.05$ (Student's T test).

ND group: rats fed with normocaloric (standard control) diet; HD group: rats fed with hypercaloric (cafeteria) diet. Data are presented as mean \pm SEM. * $\mathrm{p}<0.05$; $* * * p<0.001 ; * * \star * p<0.0001$ (two-way ANOVA followed by the Bonferroni test).

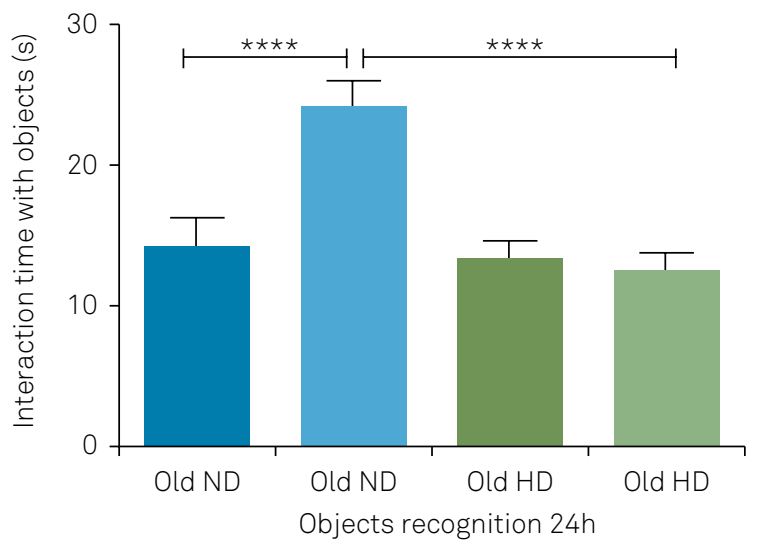

Figure 1. Time of interaction in seconds (s) with the new object and with the old one in the novel object recognition (NOR) test after 3 and 24 hours. 
As for the GFAP astrocyte expression, rat brains from the HD group showed increased reactivity $(\mathrm{p}<0.0001)$ in the arcuate and periventricular nuclei of the hypothalamus (Figure 2) as well as in the CA1, CA2 and CA3 areas of the hippocampus (Figure 3). Photomicrographs of the GFAP immunohistochemical staining in astrocytes from different areas and groups are shown in Figures 4 and 5.

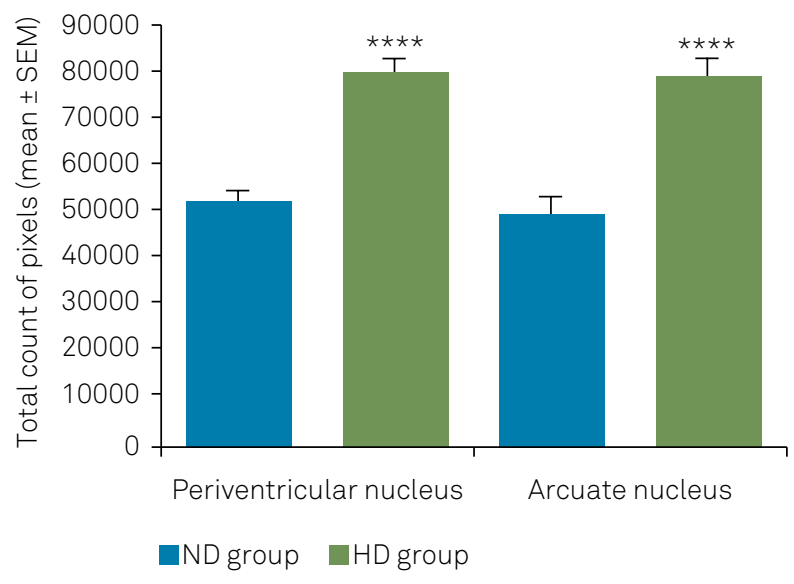

ND group: rats fed with normocaloric (standard control) diet; HD group: rats fed with hypercaloric (cafeteria) diet. Data are presented as mean (total count of pixels) \pm SEM. ${ }^{* * * *} \mathrm{p}<0.0001$ (Mann-Whitney $U$ test).

Figure 2. Glial fibrillary acidic protein (GFAP) expression by immunohistochemistry in the periventricular and arcuate nuclei of the hypothalamus.

\section{DISCUSSION}

Neuroinflammation in the CNS has been increasingly identified as a feature of obesity in animals ${ }^{9-13,18,19,20}$, not only in the hypothalamus, where it was first recognized, but also in other brain areas ${ }^{13}$. It is widely recognized that obesogenic diets induce early inflammatory effects in

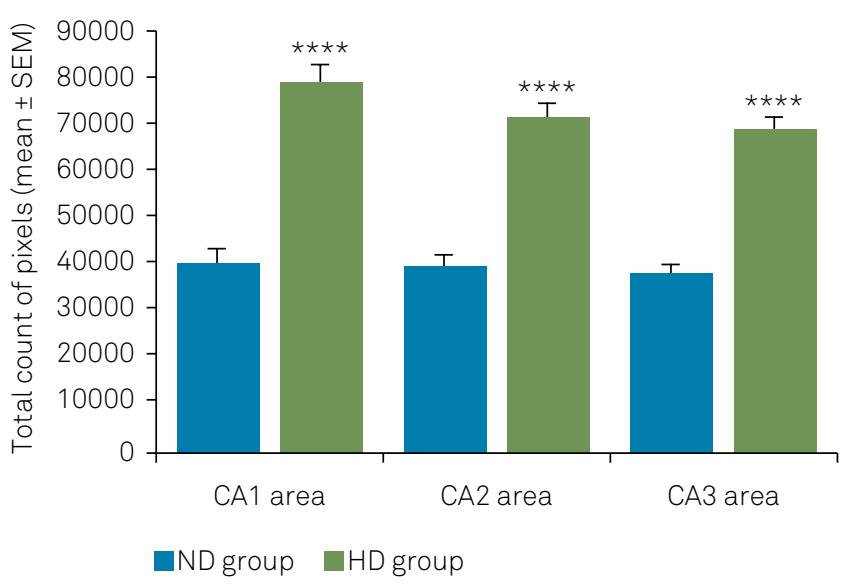

ND group: rats fed with normocaloric (standard control) diet; HD group: rats fed with hypercaloric (cafeteria) diet. Data are presented as mean (total count of pixels) \pm SEM. ${ }^{* * *} \mathrm{p}<0.0001$ (Mann-Whitney $U$ test).

Figure 3. Glial fibrillary acidic protein (GFAP) expression by immunohistochemistry in the CA1, CA2 and CA3 areas of the hippocampus.

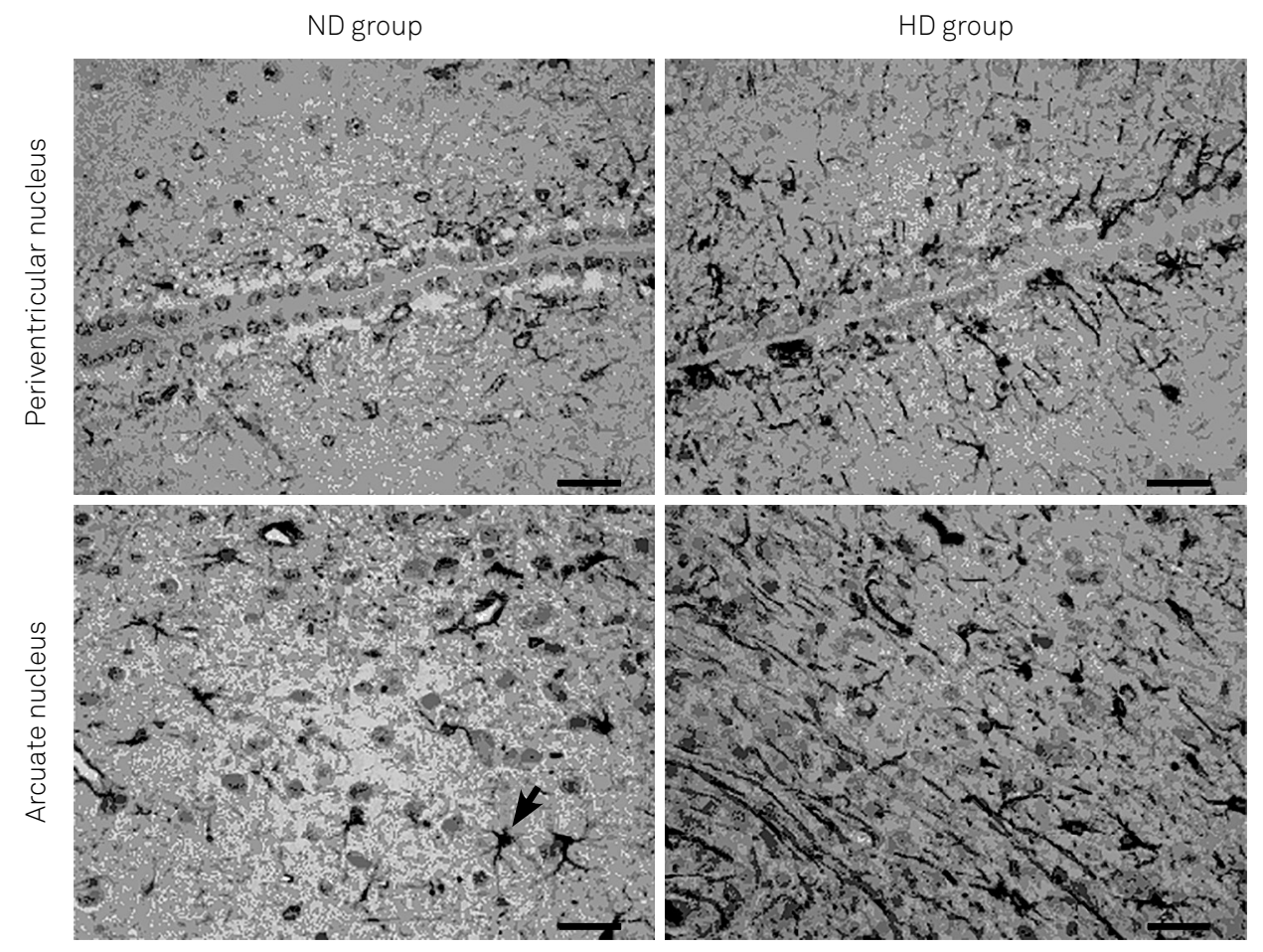

ND group: rats fed with normocaloric (standard control) diet; HD group: rats fed with hypercaloric (cafeteria) diet. Arrow: A GFAP-positive astrocyte. GFAP immunohistochemistry for astrocytes. Scale bar: $50 \mu \mathrm{m}$.

Figure 4. Photomicrographs of the periventricular and arcuate nuclei of the hypothalamus. 


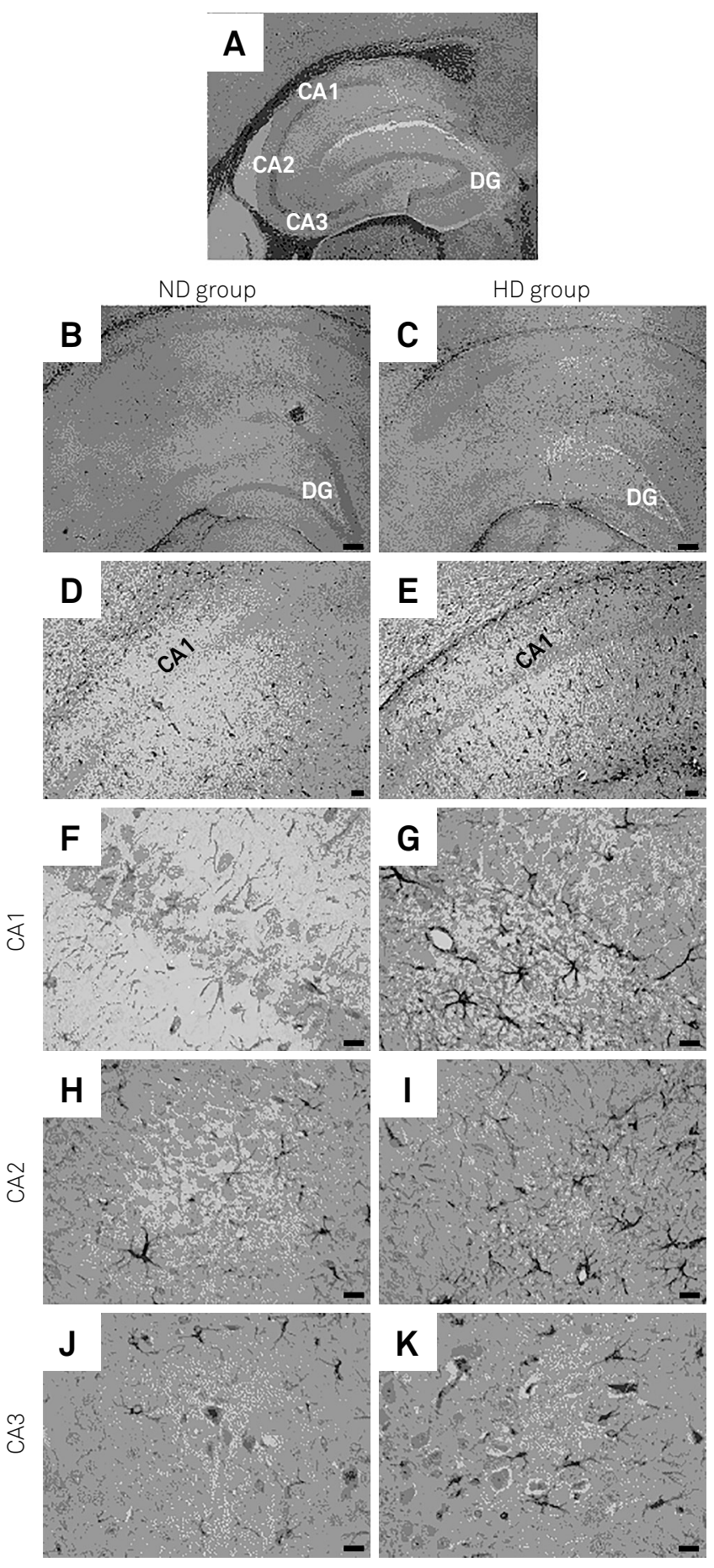

Figures a, b, scale bar: $500 \mu \mathrm{m}$; d, e, scale bar: $100 \mu \mathrm{m}$; f to k, scale bar: $50 \mu \mathrm{m}$.

Figure 5. Photomicrographs of different areas of the hippocampus. Figure a shows the spatial localization of CA1, CA2, CA3 areas and of the dentate gyrus (DG) in the hippocampus. Figures b, d, f, h, j refer to the ND group (rats fed with normocaloric diet). Figures c, e, g, i, k refer to the HD group (rats fed with a hypercaloric diet). GFAP immunohistochemistry for astrocytes.

the hypothalamus, which precede inflammatory events in peripheral tissues. Prolonged over-nutrition leads to sustained hypothalamic inflammation via interactions between neurons and non-neuronal cell populations, including glial cells, such as astrocytes, microglia and tanycytes, perpetuating the initially reversible processes and ultimately resulting in uncoupling between caloric intake and energy expenditure, fostering overeating and further weight gain ${ }^{21,22,23}$.

Alterations of the blood-brain barrier are probably involved in the development of hypothalamic inflammation, as this barrier acts as an interface between the CNS and peripheral tissues, regulating the exchange of substances between the blood and the neuropil ${ }^{23}$. A high-fat diet induces activation of inflammatory signaling pathways in astrocytes as part of a protective homeostatic response, which could restrain food intake in response to the diet. In this context, by inhibiting inflammatory signaling in astrocytes, this homeostatic response would be attenuated, resulting in increased food intake during the initial acute hyperphagic response to the high-fat diet. The nuclear factor kappa $\beta$ (NFк $\beta$ ) transcription pathway in astrocytes plays a key role in the production of proinflammatory cytokines and in the development of reactive astrogliosis. Inhibition of $\mathrm{NF} \kappa \beta$ signaling in astrocytes has been shown to prevent acute high-fat diet-induced astrocyte activation ${ }^{24}$.

Interestingly, obesity-associated astrogliosis does not occur uniformly across the hypothalamus, but is associated with microvessels, suggesting a possible response by astrocytes to changes in the blood-brain barrier and/or the peripheral circulation ${ }^{12,23}$. Interleukin (IL)- $1 \beta$ is upregulated in the CNS during high-fat diet feeding and contributes to blood-brain barrier dysfunction via the transcriptional repression of claudin-5, a tight junction protein critically involved in maintaining barrier integrity ${ }^{25,26}$. Also, long-term hyperlipidic feeding results in the expression of vascular endothelial growth factor in astrocytes and tanycytes of the hypothalamus ${ }^{27,28}$, which promotes microvessel permeability and blood-brain barrier disruption $^{23}$. Another important finding in obesity is that there is an increased expression of leptin receptors in hypothalamic astrocytes, which may suggest the sequestering of leptin by astrocytes, thus leading to decreased leptin signaling to neurons ${ }^{29}$. Finally, saturated long chain fatty acids have also been proven to activate inflammatory signaling in cultured astrocytes ${ }^{30}$.

As for the astrocytic response in the hippocampus of rodents following hypercaloric or high-fat diets, morphological findings are still controversial. Hippocampal astrogliosis was superficially reported in mice in a previous investigation $^{12}$, although this was based solely on a visual analysis, without the use of any morphometric tool.

In a study where young and aged female Wistar rats had access to a cafeteria diet or a standard chow diet, it was found that the cafeteria diet/aged group showed an increase in IL-1 levels in the cerebral cortex and hippocampus, although the number of GFAP-positive cells did 
not differ between the groups ${ }^{31}$. The GFAP or microglial Iba-1 immunoreactive area fraction in the hippocampi of rats fed for one year with a high-fat/high carbohydrate diet was decreased, while the mean number of intersections (an indirect measure of cell complexity) was lowered in GFAP-positive astrocytes, but not in Iba-1 expressing microglia ${ }^{32}$. On the other hand, increased numbers of GFAP immunoreactive astrocytes were detected in the CA1 and CA3 subfields and dentate gyrus of obese Zucker rats, which harbor a missense mutation in the leptin receptor gene $\mathrm{e}^{33}$.

Memory deficits associated with obesity have already been described in previous investigation s $^{1,2,3,34}$. Impairment in object recognition memory and an increase in GFAPpositive cells in the cerebral cortex of rats fed with a highfat diet were also reported, but with no differences in the hippocampus ${ }^{34}$. In this study, a high-fat diet was given for 20 weeks and omega-3 supplementation started in the $16^{\text {th }}$ week. Although omega-3 supplementation played an important role in reducing the neuroinflammatory profile (decreasing gene expression of pro-inflammatory cytokines TNF- $\alpha$ and IL-6), it did not reverse the memory deficit caused by the high-fat diet ${ }^{34}$.

In our investigation, rats from the HD group showed increased adiposity compared with those from the ND group and spent less time exploring the new object after three and 24 hours from habituation, revealing the occurrence of short-term and long-term memory deficits induced by the consumption of a cafeteria diet for two months.

Astrocytes are known to be pivotal in regulating glutamatergic transmission as they are responsible for most of the glutamate uptake and metabolism ${ }^{35}$. Mice on high-fat diets have shown deficits in learning and memory, along with neurochemical and electrophysiological changes compatible with glutamatergic impairment in the hippocampus ${ }^{36}$. Upregulation of the glutamate transporters GLT-1 (glutamate transporter type-1) and GLAST (astrocyte glutamate transporter) were found in the CA3 area of the mouse hippocampus after high-fat diets, with longer and less abundant astrocyte processes, although no differences in GFAP expression were observed ${ }^{36}$.

A transitory increment in GFAP in the CA3 hippocampal region, but not in the CA1 or dentate gyrus, was found with a ketogenic diet ${ }^{37}$. High-fat diets cause ventromedial hypothalamic astrocytes to use fatty acids to generate ketone bodies. These astrocyte-derived ketone bodies are probably exported to neurons where they produce excessive ATP and reactive oxygen species, which act as a signal to decrease short-term food intake ${ }^{38}$.

Contradictory results were found in C57BL-6 mice fed with a high-fat diet, with increased expression of GFAP in hippocampal astrocytes; although astrocytic processes appeared shortened, expression of GLAST and
GLT-1 transporters was downregulated and no memory loss was observed. It was suggested that this decrease of hippocampal glutamate transporters could play a critical role in the pathogenesis of metabolic disorderrelated depression ${ }^{39}$.

It has been proposed that hippocampal astrocytes possess several functions in the formation of spatial memory, through the secretion of gliotransmitters, such as glutamate, D-serine, and ATP, growth factors such as BDNF and by the expression of receptors and channels such as those of TNF- $\alpha$ and aquaporin ${ }^{40}$.

Large polypeptide growth factors and cytokines, such as IL-1, IL- 6 , TNF- $\alpha$, IFN- $\gamma$, TGF- $\beta$, among others, as well as purines (e.g., ATP), neurotransmitters (e.g., glutamate and noradrenaline), and reactive oxygen species are among the many signaling molecules that are able to trigger and regulate astrogliosis ${ }^{35,41}$.

Therefore, according to our findings, it is suggested that CNS inflammation, induced by the hypercaloric feeding, caused a vigorous astrocyte reaction in the hypothalamus and hippocampus, as seen by the increased expression of GFAP, indicating the occurrence of astrogliosis. In turn, the hippocampal astrocyte dysfunction probably led to the memory losses noticed in the obese/overweight rats (causing both short-term and long-term deficits), possibly due to an abnormal activity of astrocytes in controlling glutamate uptake and metabolism and in glutamatergic transmission in neural circuits related to memory processing in the hippocampus.

The variable (sometimes conflicting) results in the literature regarding astrocyte reaction in distinct obesity studies, as well as the discrepancies about the association of a hypercaloric diet and memory dysfunction, may be related to the different protocols used to induce obesity/overweight or to assess the cognitive/mnemonic functions in such investigations, e.g., differences of species, diets and duration of treatment. However, our investigation clearly demonstrated that all hippocampal areas analyzed, as well as the hypothalamic ones, exhibited a strong astrocyte reaction in the expression of GFAP, suggesting an intense neuroinflammatory state in the brain parenchyma. Therefore, hippocampal astrogliosis may play a role in the development of the memory deficits found in obesity.

In conclusion, hypercaloric feeding for 60 days induced short-term and long-term memory deficits (as seen in the NOR test), associated with both hypothalamic and hippocampal astrogliosis.

\section{ACKNOWLEDGMENTS}

The authors are grateful for the technical assistance of Vedovatto, P.A. 
1. Cheke LG, Bonnici HM, Clayton NS, Simons JS. Obesity and insulin resistance are associated with reduced activity in core memory regions of the brain. Neuropsychologia. 2017 Feb;96(96):137-49. https://doi.org/10.1016/j.neuropsychologia.2017.01.013

2. Prickett C, Brennan L, Stolwyk R. Examining the relationship between obesity and cognitive function: a systematic literature review. Obes Res Clin Pract. 2015 Mar-Apr;9(2):93-113. https://doi.org/10.1016/j.orcp.2014.05.001

3. Jurdak N, Lichtenstein AH, Kanarek RB. Diet-induced obesity and spatial cognition in young male rats. Nutr Neurosci. 2008 Apr;11(2):48-54. https://doi.org/10.1179/147683008X301333

4. Popoviç M, Biessels GJ, Isaacson RL, Gispen WH. Learning and memory in streptozotocin-induced diabetic rats in a novel spatial/object discrimination task. Behav Brain Res. 2001 Aug;122(2):201-7. https://doi.org/10.1016/S0166-4328(01)00186-3

5. Andersen P, Morris R, Amaral D, Bliss T, O'Keefe J. The Hippocampus Book. New York: Oxford University Press; 2007.

6. Bird CM, Burgess N. The hippocampus and memory: insights from spatial processing. Nat Rev Neurosci. 2008 Mar;9(3):182-94. https://doi.org/10.1038/nrn2335

7. Opitz B. Memory function and the hippocampus. Front Neurol Neurosci. 2014;34:51-9. https://doi.org/10.1159/000356422

8. Haslam DW, James WP. Obesity. Lancet. 2005 Oct;366(9492):1197209. https://doi.org/10.1016/S0140-6736(05)67483-1

9. Garcia-Cáceres C, Yi C-X; Tschöp MH. Hypothalamic astrocytes in obesity. Endocrinol Metab Clin North Am. 2013;42:57-66. https://doi.org/10.1016/j.ecl.2012.11.003.

10. Araújo EP, Torsoni MA, Velloso LA. Hypothalamic inflammation and obesity. Vitam Horm. 2010;82:129-43. https://doi.org/10.1016/S0083-6729(10)82007-2

11. Thaler JP, Yi CX, Schur EA, Guyenet SJ, Hwang BH, Dietrich $\mathrm{MO}$, et al. Obesity is associated with hypothalamic injury in rodents and humans.J Clin Invest. 2012 Jan;122(1):153-62. https://doi.org/10.1172/JCl59660

12. Buckman LB, Thompson MM, Moreno HN, Ellacott KL. Regional astrogliosis in the mouse hypothalamus in response to obesity.J Comp Neurol. 2013 Apr;521(6):1322-33. https://doi.org/10.1002/cne.23233

13. Bondan EF, Molina J, Dossa PD, Viebig LB, Bonamin LV, Martins $M F$, et al. Hypercaloric diet induces astrogliosis in several areas of the rat brain. J Comp Pathol. 2018 Jan;58:132. https://doi.org/10.1016/j.jcpa.2017.10.111

14. Vogel-Ciernia A, Wood AM. Examining object location and object recognition memory in mice. Curr Protoc Neurosci. 2014 Oct;69(1):8.31.1-17 https://doi.org/10.1002/0471142301.ns0831s69

15. Sik A, van Nieuwehuyzen P, Prickaerts J, Blokland A. Performance of different mouse strains in an object recognition task. Behav Brain Res. 2003 Dec;147(1-2):49-54. https://doi.org/10.1016/S0166-4328(03)00117-7

16. Mathiesen JR, DiCamillo A. Novel object recognition in the rat: a facile assay for cognitive function. Curr Protoc Pharmacol. 2010 Jun;Chapter5:Unit 5.59.. https://doi.org/10.1002/0471141755.ph0559s49

17. Paxinos G, Watson C. The rat brain in stereotaxic coordinates. 7th ed. New York: Academic Press; 2013.

18. Thaler JP, Schwartz MW. Minireview: Inflammation and obesity pathogenesis: the hypothalamus heats up. Endocrinology. 2010 Sep;151(9):4109-15. https://doi.org/10.1210/en.2010-0336

19. Cai D. Neuroinflammation and neurodegeneration in overnutrition-induced diseases. Trends Endocrinol Metab. 2013 Jan;24(1):40-7. https://doi.org/10.1016/j.tem.2012.11.003
20. Maric T, Woodside B, Luheshi GN. The effects of dietary saturated fat on basal hypothalamic neuroinflammation in rats. Brain Behav Immun. 2014 Feb;36:35-45. https://doi.org/10.1016/j.bbi.2013.09.011

21. Kälin S, Heppner FL, Bechmann I, Prinz M, Tschöp MH, Yi C-X. Hypothalamic innate immune reaction in obesity. Nat Rev Endocrinol. 2015 June;11(6):339-51. https://doi.org/10.1038/nrendo.2015.48

22. Chowen JA, Argente J, Horvath TL. Uncovering novel roles of nonneuronal cells in body weight homeostasis and obesity. Endocrinology. 2013 Sep;154(9):3001-7. https://doi.org/10.1210/en.2013-1303

23. Jais A, Brüning JC. Hypothalamic inflammation in obesity and metabolic disease. J Clin Invest. 2017 Jan;127(1):24-32. https://doi.org/10.1172/JCl88878

24. Buckman LB, Thompson MM, Lippert RN, Blackwell TS, Yull FE, Ellacott KL. Evidence for a novel functional role of astrocytes in the acute homeostatic response to highfat diet intake in mice. Mol Metab. 2014 Oct;4(1):58-63. https://doi.org/10.1016/j.molmet.2014.10.001

25. Beard RS Jr, Haines RJ, Wu KY, Reynolds JJ, Davis SM, Elliott JE, et al. Non-muscle Mlck is required for $\beta$-catenin- and Fox01-dependent downregulation of Cldn5 in IL-1 $\beta$-mediated barrier dysfunction in brain endothelial cells. J Cell Sci. 2014 Apr;127(Pt 8):1840-53. https://doi.org/10.1242/jcs.144550

26. Nitta T, Hata M, Gotoh S, Seo Y, Sasaki H, Hashimoto $\mathrm{N}$, et al. Size-selective loosening of the blood-brain barrier in claudin-5-deficient mice. J Cell Biol. 2003 May;161(3):653-60. https://doi.org/10.1083/jcb.200302070

27. Argaw AT, Asp L, Zhang J, Navrazhina K, Pham T, Mariani JN, et al. Astrocyte-derived VEGF-A drives blood-brain barrier disruption in CNS inflammatory disease. J Clin Invest. 2012 Jul;122(7):2454-68. https://doi.org/10.1172/JCl60842

28. Langlet F, Levin BE, Luquet S, Mazzone M, Messina A, Dunn-Meynell AA, et al. Tanycytic VEGF-A boosts blood-hypothalamus barrier plasticity and access of metabolic signals to the arcuate nucleus in response to fasting. Cell Metab. 2013 Apr;17(4):607-17. https://doi.org/10.1016/j.cmet.2013.03.004

29. Pan W, Hsuchou H, Xu C, Wu X, Bouret SG, Kastin AJ. Astrocytes modulate distribution and neuronal signaling of leptin in the hypothalamus of obese A vy mice. J Mol Neurosci. 2011 Mar;43(3):478-84. https://doi.org/10.1007/s12031-010-9470-6

30. Gupta S, Knight AG, Gupta S, Keller JN, Bruce-Keller AJ. Saturated long-chain fatty acids activate inflammatory signaling in astrocytes. J Neurochem. 2012 Mar;120(6):1060-71. https://doi.org/10.1111/j.1471-4159.2012.07660.x

31. Teixeira D, Cecconello AL, Partata WA, Fraga LS, Ribeiro MF, Guedes RP. The metabolic and neuroinflammatory changes induced by consuming a cafeteria diet are age-dependent. Nutr Neurosci. 2019 Apr;22(4):284-94. https://doi.org/10.1080/1028415X.2017.1380892

32. Gzielo K, Kielbinski M, Ploszaj J, Janeczko K, Gazdzinski SP, Setkowicz Z. Long-term consumption of high-fat diet in rats: effects on microglial and astrocytic morphology and neuronal nitric oxide synthase expression. Cell Mol Neurobiol. 2017 Jul;37(5):783-9. https://doi.org/10.1007/s10571-016-0417-5

33. Tomassoni D, Nwankwo IE, Gabrielli MG, Bhatt S, Muhammad AB, Lokhandwala MF, et al. Astrogliosis in the brain of obese Zucker rat: a model of metabolic syndrome. Neurosci Lett. 2013 May;543:136-41. https://doi.org/10.1016/j.neulet.2013.03.025

34. de Andrade AM, Fernandes MD, de Fraga LS, Porawski M, Giovenardi M, Guedes RP. Omega-3 fatty acids revert high-fat diet-induced neuroinflammation but not recognition memory impairment in rats. Metab Brain Dis. 2017 Dec;32(6):1871-81. https://doi.org/10.1007/s11011-017-0080-7 
35. Sofroniew MV, Vinters HV. Astrocytes: biology and pathology. Acta Neuropathol. 2010 Jan;119(1):7-35. https://doi.org/10.1007/s00401-009-0619-8

36. Cano V, Valladolid-Acebes I, Hernández-Nuño F, Merino B, Del Olmo N, Chowen JA, et al. Morphological changes in glial fibrillary acidic protein immunopositive astrocytes in the hippocampus of dietary-induced obese mice. Neuroreport. 2014 Aug;25(11):819-22. https://doi.org/10.1097/WNR.0000000000000180

37. Silva MC, Rocha J, Pires CS, Ribeiro LC, Brolese G, Leite $\mathrm{MC}$, et al. Transitory gliosis in the CA3 hippocampal region in rats fed on a ketogenic diet. Nutr Neurosci. 2005 Aug;8(4):259-64. https://doi.org/10.1080/10284150500475032

38. Le Foll C, Levin BE. Fatty acid-induced astrocyte ketone production and the control of food intake. Am J Physiol
Regul Integr Comp Physiol. 2016 Jun;310(11):R1186-92. https://doi.org/10.1152/ajpregu.00113.2016

39. Tsai SF, Wu HT, Chen PC, Chen YW, Yu M, Wang TF, et al. High-fat diet suppresses the astrocytic process arborization and downregulates the glial glutamate transporters in the hippocampus of mice. Brain Res. 2018 Dec;1700:66-77. https://doi.org/10.1016/j.brainres.2018.07.017

40. Hassanpoor H, Fallah A, Raza M. Mechanisms of hippocampal astrocytes mediation of spatial memory and theta rhythm by gliotransmitters and growth factors. Cell Biol Int. 2014 Dec;38(12):1355-66. https://doi.org/10.1002/cbin.10326

41. Sofroniew MV. Molecular dissection of reactive astrogliosis and glial scar formation. Trends Neurosci. 2009 Dec;32(12):638-47. https://doi.org/10.1016/j.tins.2009.08.002 